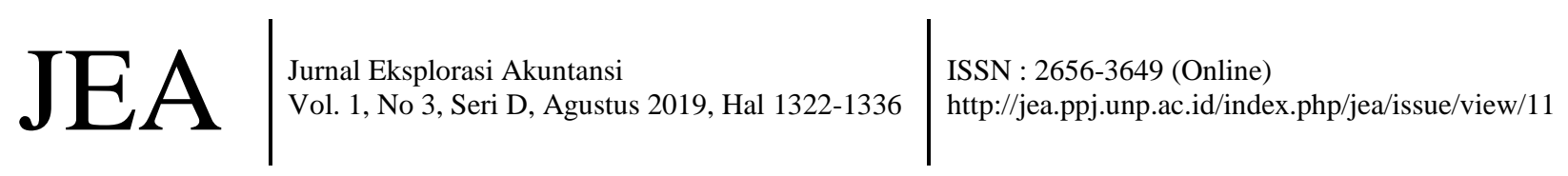

\section{PENGARUH BAGI HASIL, KELOMPOK ACUAN, KEPERCAYAAN DAN BUDAYA TERHADAP MINAT MENJADI NASABAH BANK SYARIAH}

\author{
Gicella Fanny Andriani', Halmawati ${ }^{2}$ \\ 1) Alumni Jurusan Akuntansi Fakultas Ekonomi, Universitas Negeri Padang \\ ${ }^{2)}$ Jurusan Akuntansi Fakultas Ekonomi, Universitas Negeri Padang \\ *Korespondensi: gisellafanny31@gmail.com
}

\begin{abstract}
This research aims to determine whether profit sharing, reference groups, beliefs and culture have a significant influence on the interest in being a customer of Islamic banks partially or simultaneously. A total of 95 questionnaires were returned with complete and processed conditions. By using multiple regression techniques, the results of the study show that profit sharing and reference groups do not affect the interest in becoming a customer of Islamic banks. Trust has a positive influence on the interest in becoming a customer of Islamic banks. The higher the level of trust in the bank, the higher the customer will invest funds in the bank. In addition, the culture has a positive influence on the interest of being a customer of Islamic banks, the stronger a person's culture, the interest in becoming a customer of Islamic banks will increase..
\end{abstract}

Keywords: profit sharing; reference group; beliefs; culture

\section{How to cite (APA $6^{\text {th }}$ style)}

Andriani, G.F., \& Halmawati. (2019). Pengaruh Bagi Hasil, Kelompok Acuan, Kepercayaan dan Budaya terhadap Minat Menjadi Nasabah Bank Syariah. Jurnal Eksplorasi Akuntansi, 1(3), Seri D, 1322-1336.

\section{PENDAHULUAN}

Perbankan merupakan suatu lembaga yang melakukan penghimpunan dalam bentuk pembiayaan. Sistem perbankan di Indonesia terbagi menjadi dua yaitu bank konvensional dan bank syariah. Bank konvensional adalah lembaga keuangan yang melaksanakan kegiatan dalam memberikan pelayanan berupa jasa secara umum berdasarkan prosedur yang telah ditetapkan, sedangkan Bank syariah merupakan lembaga keuangan yang menjalankan kegiatan usahanya berdasarkan prinsip-prinsip Syariat Islam.

Lahirnya Undang-undang Perbankan Syariah membuat kebutuhan masyarakat Indonesia akan jasa-jasa Perbankan Syariah di Indonesia semakin mengalami peningkatan, hal ini ditandai dengan meningkatnya Bank Umum Syariah dari sebanyak 5 bertambah menjadi 14 Bank Umum Syariah (BUS) saat ini. Peningkatan Bank Syariah telah berhasil menimbulkan persaingan antar bank, sehingga pihak bank baik konvensional maupun syariah berusaha untuk menarik masyarakat untuk berminat menjadi nasabah. Bank Syariah berusaha menarik minat nasabah dan 
calon nasabah agar tidak berpindah ke Bank lainnya dengan cara memberikan pelayanan dan keuntungan optimal dari produk yang ditawarkan oleh Bank.

Mowen dalam Oliver (2006) menjelaskan bahwa minat merupakan sesuatu yang diperoleh dari proses belajar dan pemikiran seseorang yang membentuk suatu persepsi. Anwar (2001) menjelaskan bahwa minat adalah kesukaan atau kecenderungan hati terhadap suatu hal. Theory Planned of Behavior (Teori Perilaku Terencana) yang dikemukakan oleh Ajzen (1987) mengamsumsikan bahwa kontrol perilaku atas persepsi memotivasi minat seseorang dalam memutuskan suatu hal, apabila seseorang memiliki minat yang berlebih terhadap Bank Syariah maka keinginannya untuk memutuskan menjadi nasabah pada Bank Syariah akan sangat tinggi.

Otoritas Jasa Keuangan menyebutkan bahwa jumlah pangsa pasar bank Syariah di Indonesia tahun 2018 mencapai 5,6\%, hal ini berbanding terbalik dengan pangsa pasar yang didapat oleh negara mayoritas Muslim seperti Malaysia. Pangsa pasar Perbankan Syariah di Malaysia saat ini sudah mencapai 23,8\%. Data ini menunjukkan bahwa minat masyarakat di Indonesia dalam menggunakan jasa Perbankan Syariah masih kurang sehingga Bank Syariah masih tertinggal jauh jika dibandingkan dengan pangsa Bank Syariah di Negara Muslim lainnya. Data statistik Sumatera Barat menunjukkan total aset meningkat sebesar 3,51\% dan Dana Pihak Ketiga meningkat sebesar $11,27 \%$.

Peningkatan ini tidak signifikan jika dibandingkan dengan tahun sebelumnya, total aset Perbankan Syariah Sumatera Barat berhasil meningkat sebesar 6,18\% dan Dana Pihak Ketiga sebesar 11,30\%. Menurut Ronny P. Sasmita, Analisis Ekonomi Politik Financeroll Indonesia dalam haluanharian.com, lambatnya pertumbuhan aset dan DPK Sumatera Barat diakibatkan masih tingginya suku bunga DPK pada Bank Konvensional sehingga masyarakat lebih tertarik menyimpan dananya di Bank Konvensional dibandingkan Bank Syariah. Kondisi seperti ini menjadikan pekerjaan bagi pihak Bank Syariah di Indonesia untuk meraih pangsa pasar Perbankan Nasional dan dapat mempertahankan nasabahnya agar tidak pindah ke Bank lain serta dapat menarik minat masyarakat sebanyak mungkin untuk menjadi nasabah Bank Syariah.

Andespa (2017) yang melakukan penelitian mengenai faktor-faktor yang mempengaruhi nasabah menabung di Bank Syariah. Hasilnya menunjukkan bahwa terdapat berbagai faktor yang dapat mempengaruhi minat masyarakat menjadi nasabah pada Bank Syariah yaitu faktor bauran pemasaran, faktor sosial, faktor budaya dan faktor pribadi. Faktor pertama adalah bauran pemasaran. Bauran pemasaran merupakan faktor yang dapat mempengaruhi seseorang untuk menabung di Bank Syariah. salah satunya yaitu dengan adanya persepsi bagi hasil. Christianti (2017) menemukan bahwa faktor yang paling dominan dalam mempengaruhi minat menjadi nasabah adalah tingkat bagi hasil. Tingkat bagi hasil merupakan salah satu faktor bauran pemasaran yang dilakukan Perbankan untuk menarik konsumen agar konsumen berminat melakukan pembiayaan di Bank tersebut.

Faktor lainnya yang mempengaruhi minat masyarakat menjadi nasabah Bank Syariah adalah faktor sosial. Salah satu faktor sosial yang dapat mempengaruhi minat masyarakat menjadi nasabah ialah kelompok acuan. Perilaku nasabah sangat dipengaruhi oleh kelompok acuan, seperti pada perilaku, konsumssi, gaya hidup baru, konsep pribadi, kebiasaan dan pilihan produk dan merek. Nisak (2014) yang melakukan penelitian tentang Pengaruh kelompok acuan dan pengetahuan tentang Perbankan Syariah terhadap minat menabung di Perbankan Syariah Semarang menyatakan bahwa kelompok acuan berpengaruh positif terhadap minat menabung masyarakat di Perbankan Syariah. 
Faktor ketiga yang dapat mempengaruhi minat seseorang untuk menjadi nasabah ialah faktor pribadi. Kepercayaan merupakan keyakinan seseorang terhadap orang lain dalam melakukan hubungan transaksi atau komitmen, bahwa pihak tersebut akan memenuhi kewajiban secara baik sesuai yang diharapkan dan menerima resiko yang akan di terima. Setiap nasabah selalu berharap mendapatkan keuntungan dari dana yang disimpannya pada Bank, setiap nasabah selalu mengharapkan penuh atas setiap penarikan danannya yang ditabung di Bank. Nasabah akan memilih bank yang benar-benar dapat dipercaya sebagai tempat mereka menitipkan dananya.

Faktor keempat yang dapat mempengaruhi minat menjadi nasabah adalah faktor budaya. Budaya adalah seluruh kepercayaan, nilai-nilai, pemikiran, sombol, kebiasaaan dan perilaku dalam suatu kelompok masyarakat. Perbankan Syariah dalam melakukan pemasaran dapat dilakukan dengan memahami budaya suatu masyarakat, dengan memahami budaya masyarakat maka pihak manajemen akan dapat merencanakan strategi pemasaran pada penpitaan produk, segmentasi, promosi dan menciptakan minat nasabah. Budaya masyarakat dipelajari sejak seorang nasabah masih kecil, sehingga nasabah bisa memulai mendapatkan nilai-nilai keyakinan dan kebiasaan dari lingkungannya.

\section{REVIU LITERATUR}

\section{Theory Planned of Behavior (Teori Tindakan Beralasan)}

Hubungan Theory of Planned Behavior (Teori PerilakuTerencana) dengan penelitian ini ialah perilaku manusia dapat dipengaruhi dari niat atau minat seseorang. Teori ini dapat digunakan untuk memprediksi niat individu menjadi nasabah di Bank Syariah. Minat menjadi nasabah bergantung pada suatu perilaku dan sejauh mana dia memilih untuk melakukan tindakan tersebut dia akan mendapat dukungan dari orang lain yang mempunyai pengaruh penting dalam hidupnya misalnya ajakan keluarga yang telah menjadi nasabah pada bank syariah..

\section{Perbankan Syariah}

Bank syariah biasa disebut Islamic Banking atau Interest Fee Banking, yaitu sistem perbankan dalam pelaksanaan operasional tidak menggunakan sistem bunga (riba), ketidak pastian atau ketidak jelasan (gharar), dan sepkulasi (maisir).Bank Syariah adalah bank yang menjalankan kegiatan operasionalnya berdasarkan Prinsip Islam dan menurut jenisnya terdiri dari Bank Umum Syariah, Unit Usaha Syariah dan Bank Pembiayaan Rakyat Syariah (Saidurrahman, 2014).

\section{Minat Menjadi Nasabah Bank Syariah}

Minat menjadi nasabah dalam penelitian ini diartikan sebagai kecenderungan seseorang untuk bertindak sebelum membuat keputusan menjadi nasabah di Bank Syariah. Kotler (2002) yang mengemukakan bahwa minat beli konsumen adalah sesuatu yang timbul setelah menerima dorongan untuk membeli produk yang dilihatnya kemudian timbul ketertarikan untuk mencoba dan membeli agar dapat memilikinya.

\section{Bagi Hasil}

Bagi hasil merupakan sistem yang meliputi tata cara pembagian hasil usaha yang telah disepakati oleh pemilik dana dan pengelola dana atas keuntungan yang didapat. Bentuk produk yang menggunakan prinsip bagi hasil adalah mudharabah dan musyakarah. Prinsip bagi hasil 
merupakan karakteristik umum dan landasan dasar bagi kegiatan operasional Perbankan Syariah secara keseluruhan, dimana Bank Syariah berdasarkan mudharabah menjadikan bank sebagai mitra bagi nasabah ataupun yang peminjam dana.

\section{Kelompok Acuan}

Kelompok acuan adalah orang atau sejenis kelompok yang lebih spesifik dapat mempangaruhi tindakan seseorang.kelompok acuan dapat dijadikan sebagai pedoman dalam selera konsumsi seseorang sehingga menyebabkan sebagian kalangan masyarakat mengikuti selera mereka.

\section{Kepercayaan}

Kepercayaan merupakan keyakinan seseorang untuk menemukan apa yang diinginkan. Kepercayaan melibatkan seseorang bersedia untuk melakukan tindakan tertentu karena yakin bahwa mitranya akan memberikan apa yang ia harapkan dan suatu harapan yang umumnya dimiliki seseorang bahwa perkataan, janji, atau pernyataan orang lain dapat dipercaya.

\section{Budaya}

Menurut Sunarwan (2011), budaya merupakan segala nilai, pemikiran, simbol yang dapat mempengaruhi perilaku, sikap,kepercayaan dan kebiasaan seseorang atau masyarakat. Budaya adalah seluruh kepercayaan, nilai-nilai, pemikiran, simbol,kebiasaan dan perilaku dalam suatu masyarakat.

\section{Pengaruh Bagi Hasil Terhadap Minat Menjadi Nasabah Bank Syariah}

Bagi hasil adalah suatu sistem pengolahan dana dalam perekonomian Islam yakni pembagian hasil usaha antara pemilik modal dan pengelola. Semakin tinggi nisbah bagi hasil dan semakin jelas ketentuan dalam pembagian bagi hasil maka dapat memperbesar kemungkinan nasabah dalam mempengaruhi minat untuk menggunakan jasa Perbankan Syariah. Wahab (2014) menemukan bahwa tingkat bagi hasil merupakan faktor utama seseorang dalam memutuskan menjadi nasabah pada Bank Syariah, hal ini terjadi karena tingkat bagi hasil begitu dominan dalam mendoroang seseorang untuk membuka rekening Bank Syariah.

Wahyuni (2017) menemukan bahwa bagi hasil berpengaruh positif signifikan terhadap minat menjadi nasabah, hal ini disebabkan karena nasabah yakin semakin tinggi nisbah bagi hasil maka semakin besar keuntungan yang didapat dan pihak bank bisa mengoptimalkan bagi hasil untuk tidak merugikan nasabah.Berdasarkan penelitian dan penyataan terdahulu, maka penulis merumuskan hipotesis sebagai berikut :

H1: Bagi Hasil berpengaruh positif signifikan terhadap Minat Menjadi Nasabah Bank Syariah.

\section{Pengaruh Kelompok Acuan Terhadap Minat Menjadi Nasabah Bank Syariah}

Kelompok acuan yang memiliki pengaruh tidak langsung disebut kelompok acuan sekunder seperti kelompok agama, profesional/formal, dan kelompok asosiasi perdagangan sedangkan kelompok acuan langsung disebut kelompok acuan primer seperti keluarga, rekan kerja dan teman. Andespa (2017) menemukan bahwa kelompok acuan berpengaruh positif terhadap minat menjadi nasabah Bank Syariah.

Ketika calon nasabah meminta pendapat kepada seseorang atau kelompok yang ia temui dalam kesehariannya dan berinteraksi dengan yang telah menggunakan jasa Perbankan Syariah, maka orang tersebut akan merekomendasikan kepada seseorang atau calon nasabah untuk 
menggunakan jasa Perbankan Syariah karena menurutnya Bank Syariah adalah yang paling tepat. Maka hal ini akan mendorong calon nasabah untuk menjadi nasabah di Bank Syariah. Berdasarkan penelitian dan pernyataan terdahulu, maka penulis merumuskan hipotesis sebagai berikut :

H2: Kelompok acuan berpengaruh positif signifikan terhadap minat menjadi nasabah Bank Syariah.

\section{Pengaruh Kepercayaan Terhadap Minat Menjadi Nasabah Bank Syariah}

Kusmayadi (2007) menjelaskan bahwa kepercayaan merupakan keyakinan seseorang akan menemukan apa yang ia inginkan pada mitra pertukaran. Faidhatul Fitri (2016), Menyatakan bahwa kepercayaan nasabah pada bank syariah akan mempengaruhi minat nasabah dalam bertransaksi dan menitipkan dananya pada Bank, karena dengan adanya kepercayaan yang tinggi maka nasabah yakin bahwa pihak Bank mampu bertanggung jawab akan tugasnya. Jika nasabah percaya dan yakin akan suatu kinerja Bank dalam mengelola dana nasabah, maka minat nasabah dalam menitipkan dananya dan melakukan transaksi pada Bank tersebut semakin meningkat. Berdasarkan uraian diatas, maka hipotesis untuk penelitian ini adalah :

$\mathbf{H}_{3}$ : Kepercayaan berpengaruh positif signifikan terhadap minat menjadi nasabah Bank Syariah.

\section{Pengaruh Budaya Terhadap Minat Menjadi Nasabah Bank Syariah}

Kotler (2011) menjelaskan bahwa budaya merupakan penentu keinginan dan perilaku yang paling mendasar seorang konsumen dalam melakukan pembelian. Setiap kelompok atau masyarakat memiliki budaya dan penagruh budaya pada perilaku pembelian anggotamya yang sangat beraneka ragam. Ketika nasabah menggunakan jasa Perbankan, mereka berharap jasa tersebut menjalankan fungsi sesuai dengan yang diharapkan dan nasabah akan terus menggunakan apabila harapannya dipenuhi dengan baik.

Seorang nasabah memutuskan untuk menitipkan dananya pada Bank akan melakukan pertimbangan berdasarkan budaya yang berkembang dilingkungan tempat tinggalnya. Semakin kuat budaya yang dipegang oleh seseorang, maka semakin sulit untuk merubah keputusannya, artinya semakin besar pengaruh budaya pada seseorang, maka semakin besar keputusannya untuk menitipkan dananya di Perbankan Syariah. Berdasarkan uraian diatas maka hipotesis dalam penelitian ini adalah :

H4: Budaya berpengaruh positif signifikan terhadap minat menjadi nasabah Bank Syariah.

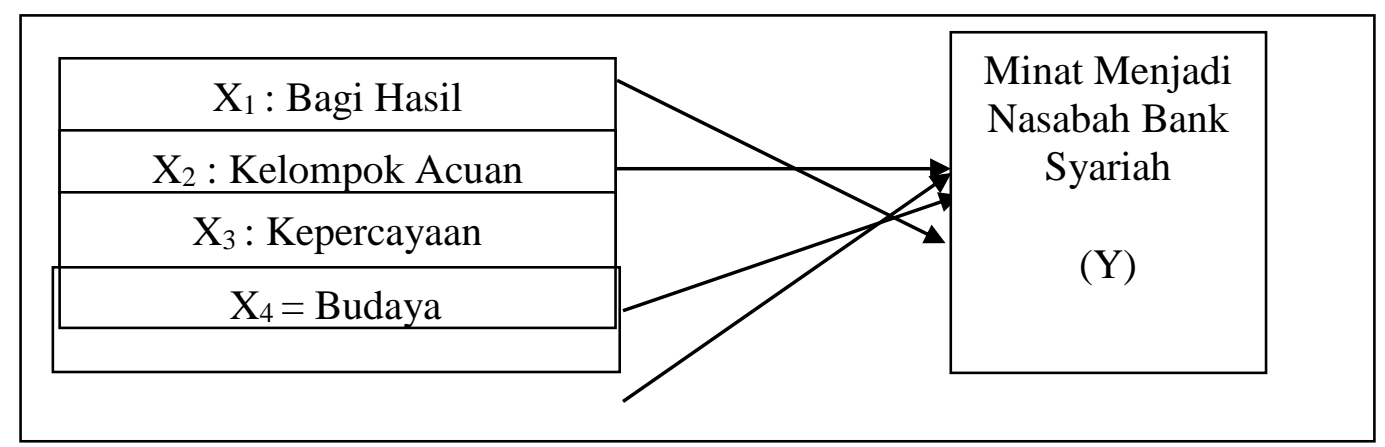




\section{METODE PENELITIAN}

\section{Desain Penelitian}

Penelitian ini merupakan penelitian dengan menggunakan metode kuantitatif dimana penelitian ini bertujuan untuk memberikan gambaran dan menguji secara empiris pengaruh variabel bebas yang terdiri dari Bagi Hasil, Kelompok Acuan, Kepercayaan dan Budaya dengan variabel terikat Minat menjadi Nasabah Bank Syariah di kota Padang.

\section{Populasi, Sampel, dan Teknik Pengambilan Sampel}

Populasi dalam penelitian ini adalah Nasabah Bank Syariah di Kota Padang sebanyak 371.226 nasabah (OJK,2018). Jumlah sampel dalam penelitian ini sebanyak 100 responden nasabah bank syariah yang pernah melakukan transaksi di bank syariah yang ada di kota Padang.

\section{Jenis, Sumber Data, dan Teknik Pengumpulan Data}

Dalam memperoleh data pada penelitian ini peneliti menggunakan dua cara yaitu penelitian lapangan (field research) sebagai data primer dan penelitian kepustakaan (library research) sebagai data sekunder. Pengumpulan data dilakukan dengan cara survey kuesioner yaitu pengumpulan data melalui pemberian daftar pertanyaan dan dilengkapi dengan beberapa alternatif jawaban kepada responden.

\section{Instrumen variabel penelitian}

a. Minat Menjadi Nasabah Bank Syariah (Y)

Minat menjadi nasabah dalam penelitian ini diartikan sebagai kecenderungan seseorang untuk bertindak sebelum membuat keputusan menjadi nasabah di Bank Syariah.

b. Bagi Hasil (X1)

Bagi hasil merupakan sistem pembagian hasil antara pihak bank dengan nasabah. Di dalam bagi hasil tersebut ada pembagian hasil atas keuntungan yang akan di dapat antara kedua belah pihak atau lebih. Wujud bagi hasil berupa nisbah serta dijelaskan ketentuannya seperti pembagian keuntungan, jaminan dari bagi hasil, dan besarnya nisbah keuntungan.

c. Kelompok Acuan (X2)

Kelompok acuan adalah sejumlah jenis kelompok yang lebih spesifik. Faktor umum diantara semua jenis kelompok acuan adalah bahwa mereka digunakan oleh para anggota sebagai titik acuan untuk mengevaluasi kebenaran tindakan, kepercayaan dan sikap mereka.

d. Kepercayaan (X3)

Kepercayaan melibatkan seseorang bersedia untuk melakukan tindakan tertentu karena yakin bahwa mitranya akan memberikan apa yang ia harapkan dan suatu harapan yang umumnya dimiliki seseorang bahwa perkataan, janji, atau pernyataan orang lain dapat dipercaya

e. Budaya (X4)

Budaya merupakan penentu keinginan dan perilaku yang paling mendasar. Setiap atau masyarakat memiliki budaya dan pengaruh budaya pada perilaku atas pembelian anggotanya yang sangat beragam. 


\section{HASIL DAN PEMBAHASAN}

\section{Analisis Induktif}

\section{a. Uji Asumsi Klasik}

\section{Uji Normalitas}

Uji normalitas digunakan untuk menguji apakah data mengikuti atau mendekati distribusi normal atau tidak. Alat uji yang digunakan dalam uji asumsi klasik adalah Kolmogorovsmirnov (1-Sample $K$-S). Hasil pengolahan SPSS versi 21 didapat bahwa hasiluji normalitas menunjukkan level signifikasi lebih besar dari $\alpha(\alpha=0,05)$ yaitu $1,00>0,05$ sehingga data terdistribusi secara normal seperti dibawah ini :

\section{Uji Normalitas}

\section{One-Sample Kolmogorov-Smirnov Test}

\begin{tabular}{|c|c|c|}
\hline & & $\begin{array}{c}\text { Unstandardized } \\
\text { Residual }\end{array}$ \\
\hline $\mathrm{N}$ & & 95 \\
\hline \multirow{3}{*}{ Normal Parameters ${ }^{\mathrm{a}, \mathrm{b}}$} & Mean & $0 \mathrm{E}-7$ \\
\hline & Std. Deviation & 2,39846727 \\
\hline & Absolute & 035 \\
\hline \multirow[t]{2}{*}{ Most Extreme Differences } & Positive & 035 \\
\hline & Negative &,- 032 \\
\hline Kolmogorov-Smirnov Z & & ,345 \\
\hline Asymp. Sig. (2-tailed) & & 1,000 \\
\hline
\end{tabular}

a. Test distribution is Normal.

b. Calculated from data.

Berdasarkan tabel 4.10 di atas menunjukkan bahwa asymp sig (2-failed) sebesar 1,00 yang besar dari nilai signifikansi 0,05 , jadi dapat disimpulkan bahwa data yang digunakan dalam peneitian ini berdistribusi normal sehingga dapat memenuhi uji normalitas dan data yang digunakan.

\section{Uji Multikolenearitas}

\section{Uji Multikolenearitas}

\begin{tabular}{|c|c|c|c|}
\hline \multirow{2}{*}{\multicolumn{2}{|c|}{ Model }} & \multicolumn{2}{|c|}{ Collinearity Statistics } \\
\hline & & Tolerance & VIF \\
\hline & (Constant) & & \\
\hline & TOTALX1 & , 170 & 5,894 \\
\hline 1 & TOTALX2 & ,291 & 3,436 \\
\hline & TOTALX3 & ,308 & 3,249 \\
\hline & TOTALX4 &, 719 & 1,390 \\
\hline
\end{tabular}

a. Dependent Variable: TOTALY1 
Berdasarkan tabel 4.11 diatas dapat dilihat bahwa variabel bagi hasil dengan nilai (VIF) 5,894 dan tolerance 0,170, variabel kelompok acuan memiliki nilai (VIF) sebesar 3,436 dan tolerance 0,291, variabel kepercayaan memiliki nilai (VIF) 3,249 dengan tolerance 0,38, dan variabel budaya dengan nilai (VIF) 1,390 dengan tolarance 0,719. Dengan demikian dapat dikatakan tidak terdapat korelasi variabel-variabel independen antara satu dengan yang lainnya. Variabel independen dalam penelitian ini bebas dari gejala multikolenearitas.

\section{Uji Heteroskedastisitas}

\section{Coefficients $^{\mathrm{a}}$}

\begin{tabular}{|c|c|c|c|c|c|c|}
\hline \multirow{2}{*}{\multicolumn{2}{|c|}{ Model }} & \multicolumn{2}{|c|}{ Unstandardized Coefficients } & \multirow{2}{*}{$\begin{array}{c}\begin{array}{c}\text { Standardized } \\
\text { Coefficients }\end{array} \\
\text { Beta }\end{array}$} & \multirow[t]{2}{*}{$\mathrm{T}$} & \multirow[t]{2}{*}{ Sig. } \\
\hline & & B & Std. Error & & & \\
\hline \multirow{5}{*}{1} & (Constant) & 3,833 & 1,077 & & 3,557 & ,001 \\
\hline & TOTALX1 &,- 115 & ,085 &,- 334 & $-1,345$ &, 182 \\
\hline & TOTALX2 &, 030 & 220 & ,026 & 137 & ,892 \\
\hline & TOTALX3 & 036 & 056 &, 120 & ,651 &, 517 \\
\hline & TOTALX4 &,- 007 & 034 &,- 025 &,- 204 & ,839 \\
\hline
\end{tabular}

a. Dependent Variable: Abs_RES

Sumber : Data Primer yang diolah, 2019

Berdasarkan tabel diatas maka dapat dilihat bahwa hasil perhitungan dari masing-masing variabel menunjukkan bahwa level sig $>\alpha 0,05$. Nilai signifikansi untuk variabel bagi hasil (X1) $0,182>0,05$, nilai signifikansi untuk variabel kelompok acuan (X2) 0,892>0,05, nilai signifikansi untuk variabel kepercayaan (X3) 0,517>0,05, dan selanjutnya nilai signifikansi untuk variabel budaya (X4) 0,839>0,05. Jadi dapat disimpulkan bahwa model regresi yang digunakan dalam penelitian ini bebas dari gejala heteroskedastisitas dan layak untuk diteliti.

\section{Uji Hipotesis}

\section{Analisis Regresi Berganda}

Coefficients $^{\mathbf{a}}$

\begin{tabular}{|c|c|c|c|c|c|c|}
\hline \multirow{2}{*}{\multicolumn{2}{|c|}{ Model }} & \multicolumn{2}{|c|}{ Unstandardized Coefficients } & \multirow{2}{*}{$\begin{array}{c}\begin{array}{c}\text { Standardized } \\
\text { Coefficients }\end{array} \\
\text { Beta }\end{array}$} & \multirow[t]{2}{*}{$\mathrm{T}$} & \multirow[t]{2}{*}{ Sig. } \\
\hline & & B & Std. Error & & & \\
\hline \multirow{5}{*}{1} & (Constant) & 14,966 & 1,833 & & 8,163 & ,000 \\
\hline & TOTALX1 &,- 261 &, 145 &,- 364 & $-1,797$ & ,076 \\
\hline & TOTALX2 & ,593 & ,374 & ,246 & 1,587 & , 116 \\
\hline & TOTALX3 & ,226 & ,095 & ,358 & 2,380 & ,019 \\
\hline & TOTALX4 & ,269 &, 058 & ,458 & 4,649 & ,000 \\
\hline
\end{tabular}

a. Dependent Variable: TOTALY1

Sumber : Data Primer yang diolah, 2019 
Berdasarkan tabel 4.14 diatas dapat analisis model persamaan sebagai berikut :

$$
Y=14,966-0,261+0,593+0,226+0,269+e
$$

Keterangan :

$\mathrm{Y}=$ Minat Menjadi Nasabah Bank Syariah

$\mathrm{X}_{1}=$ Bagi Hasil

$\mathrm{X}_{2}=$ Kelompok Acuan

$\mathrm{X}_{3}=$ Kepercayaan

$\mathrm{X}_{4}=$ Budaya

Berdasarkan persamaan regresi di atas dapat dijelaskan sebagai berikut :

a. Nilai konstanta yang diperoleh sebesar 14,966 berarti jika variabel independen bernilai 0 , maka nilai variabel dependen adalah 14,966.

b. Nilai koefisien sebesar $-0,261$, nilai ini menunjukkan bahwa setiap penambahan satu satuan variabel dari bagi hasil akan menurunkan minat menjadi nasabah bank syariah sebesar 0,261

c. Nilai koefisien sebesar 0,593, nilai ini menunjukkan bahwa setiap penambahan satu satuan variabel dari kelompok acuan akan meningkatkan minat menjadi nasabah bank syariah sebesar 0,593.

d. Nilai koefisien sebesar 0,226 menunjukkan bahwa setiap penambahan satu satuan dari kepercayaan maka akan meningkatkan minat menjadi nasabah bank sayriah sebesar 0,226.

e. Nilai koefisien sebesar 0,269 menunjukkan bahwa setiap penambahan satu satuan variabel dari budaya daoat meningkatkan minat menjadi nasabah bank syariah sebesar 0,269.

\section{b. Uji Kelayakan Model}

\section{Koefisien Determinasi $R^{2}$}

Uji Adjusted $R^{2}$

\begin{tabular}{|c|c|c|c|c|c|}
\hline \multicolumn{6}{|c|}{ Model Summary } \\
\hline Model & $\mathrm{R}$ & R Square & Adjusted R Squ & & $\begin{array}{l}\text { Std. Error of } \\
\text { Estimate }\end{array}$ \\
\hline 1 &, $610^{\mathrm{a}}$ & ,372 & ,344 & & 2,451 \\
\hline \multicolumn{6}{|c|}{ a. Predictors: (Constant), TOTALX4, TOTALX2, TOTALX3, TOTALX1 } \\
\hline & $\mathrm{R}$ & R Square & Adjusted R Square & & $\begin{array}{l}\text { Error of the } \\
\text { stimate }\end{array}$ \\
\hline & $.392^{\mathrm{a}}$ & .153 & .126 & & 2.67435 \\
\hline
\end{tabular}

Sumber:Data primer yang diolah,2019 
Tabel 4.15 menunjukkan nilai koefisien Adjusted R Square adalah sebesar 0,344. Hal ini mengidentifikasikan bahwa kontribusi variabel independen terhadap variabel dependen adalah sebesar $34,4 \%$, sedangkan $65,6 \%$ lainnya dijelaskan oleh faktor-faktor lain yang tidak diketahui dan tidak termasuk dalam penelitian.

\section{Uji F}

Berdasarkan analisis data yang diperoleh menguji hipotesis ini, maka dilakukan uji $\mathrm{F}$ dengan membandingkan nilai $F_{\text {hitung }}$ untuk $n=95$ adalah 2,47. Hasil pengolahan statistik analisis regresi menunjukkan nilai $F=13,339$ dan signikan pada level 0,00. Jadi $F_{\text {hitung }}>F_{\text {tabel }}$ yaitu 13,339 > 2,47 ( $\operatorname{sig} 0,00<0,05$ ). Hal ini menunjukkan bahwa model regresi dapat digunakan untuk menguji pengaruh variabel independen terhadap varabel dependen.

\section{Uji Statistik F}

ANOVA ${ }^{a}$

\begin{tabular}{|c|c|c|c|c|c|}
\hline Model & $\begin{array}{l}\text { Sum of } \\
\text { Squares }\end{array}$ & Df & $\begin{array}{c}\text { Mean } \\
\text { Square }\end{array}$ & $\mathrm{F}$ & Sig. \\
\hline $\begin{array}{l}\text { Regression } \\
\text { Residual } \\
\text { Total }\end{array}$ & $\begin{array}{l}320,578 \\
540,749 \\
861,326\end{array}$ & $\begin{array}{r}4 \\
90 \\
94\end{array}$ & $\begin{array}{r}80,144 \\
6,008\end{array}$ & 13,339 &, $000^{\mathrm{b}}$ \\
\hline
\end{tabular}

a. Dependent Variable: TOTALY1

b. Predictors: (Constant), TOTALX4, TOTALX2, TOTALX3, TOTALX1

Sumber : Data Primer yang diolah, 2019

\section{Uji Hipotesis (t-test)}

Uji hipotesis dilakukan dengan menggunakan uji t. Uji t dilakukan untuk menguji apakah masing-masing variabel independen berpengaruh secara signifikan terhadap variabel dependen. Pengujian hipotesis secara parsial dilakukan dengan cara membandingkan nilai $t_{\text {hitung }}$ dengan nilai $t_{\text {tabel. Nilai }} \mathrm{t}_{\text {tabel }}$ adalah $\alpha=0,05$ dengan derajat bebas $(\mathrm{db})-\mathrm{n}-\mathrm{k}=95-5=$ 90 adalah 1,986 .

\section{a. Hipotesis 1}

Pengujian hipotesis dilakukan dengan membandingkan $t$ hitung dengan nilai $t$ tabel. Hipotesis diterima jika $t$ hitung $>\mathrm{t}$ tabel atau nilai sig $<0,05$. Variabel bagi hasil thitung sebesar negatif $1,797<1,986$ dengan tingkat signifikansi $0,076>0,05$. Hal ini menujukkan bahwa penelitian ini tidak dapat membuktikan bagi hasil berpengaruh positif terhadap minat menjadi nasabah bank syariah. Dengan demikian ipotesis pertama $\left(\mathrm{H}_{1}\right)$ ditolak.

\section{b. Hipotesis 2}

Hasil pengujian untuk variabel kelompok acuan memiliki t hitung sebesar 1,687 dengan tingkat signifikansi 0,116>0,05. Hal ini menunjukkan bahwa penelitian ini tidak dapat membuktikan kelompok acuan berpengaruh positif terhadap minat menjadi nasabah bank syariah. Dengan demikian hipotesis kedua $\left(\mathrm{H}_{2}\right)$ ditolak. 


\section{c. Hipotesis 3}

Hasil pengujian untuk variabel kepercayaan memiliki t hitung sebesar 2,380 dengan tingkat signifikansi $0,019<0,05$. Hal ini membuktikan kepercayaan bepengaruh positif terhadap minat menjadi nasabah bank syariah. Dengan demikian hipotesis ketiga $\left(\mathrm{H}_{3}\right)$ diterima.

\section{d. Hipotesis 4}

Hasil pengujian untuk variabel budaya memiliki nilai t hitung sebesar 4,649 dengan tingkat signifikansi $0,00<0,05$ artinya hipotesis keempat diterima. Hal ini membuktikan budaya bepengaruh terhadap minat menjadi nasabah bank syariah. Dengan demikian hipotesis keempat $\left(\mathrm{H}_{4}\right)$ diterima.

\section{PEMBAHASAN}

\section{Pengaruh Bagi Hasil Terhadap Minat Menjadi Nasabah Bank Syariah}

Hasil pengujian bagi hasil nilai koefisien yang dihasilkan negatif 0,261 nilai ini menujukkan bahwa setiap penambahan satu satuan dari bagi hasil, maka akan menurunkan minat menjadi nasabah bank syariah sebesar 0,261. Nilai t hitung sebesar negatif 1,797 dengan tingkat probabilitas signifikansi 0,076 >0,05. Artinya hipotesis pertama ditolak dengan kata lain bagi hasil tidak memiliki pengaruh terhadap minat menjadi nasabah bank syariah, secara teoritis konsep ini kurang mendukung minat menabung nasabah tidak seperti yang diutarakan oleh Christianti (2017) yang menyatakan bahwa bagi hasil adalah faktor yang paling dominan dalam mempengaruhi seseorang menggunakan jasa perbankan syariah. Namun penelitian ini mendukung penelitian yang dilakukan oleh Prassetio (2017) yang membuktikan bahwa bagi hasil tidak berpengaruh terhadap minat menjadi nasabah bank syariah pada masyarakat Tangerang Selatan.

\section{Pengaruh Kelompok Acuan Terhadap Minat Menjadi Nasabah Bank Syariah}

Hasil pengujian bagi hasil nilai koefisien yang dihasilkan 0,593 nilai ini menujukkan bahwa setiap penambahan satu satuan dari bagi hasil, maka akan meningkatkan minat menjadi nasabah bank syariah sebesar 0593. Nilai t hitung sebesar 1,587 dengan tingkat probabilitas signifikansi $0,116>0,05$. Artinya hipotesis pertama kedua ditolak dengan kata lain kelompok acuan tidak berpengaruh terhadap minat menjadi nasabah bank syariah. Hasil penelitian ini sejalan dengan penelitian yang dilakukan oleh Rahman (2013) yang membuktikan bahwa kelompok acuan tidak berpengaruh positif terhadap minat menjadi nasabah bank syariah. Secara teori Sukarno (2013) dapat dijelaskan bahwa kelompok acuan merupakan kelompok yang memiliki pengaruh langsung atau tidak langsung. Dalam teori perilaku terencana yang mana perilaku seseorang dihasilkan dari lingkungan sosial sehingga dapat mempengaruhi minat seseorang. Namun dalam penelitian ini kelompok acuan tidak mendukung dalam teori yang yang ada yang menunjukkan bahwa kelompok acuan berpengaruh terhadap minat menjadi nasabah bank syariah.

\section{Pengaruh Kepercayaan Terhadap Minat Menjadi Nasabah Bank Syariah}

Hasil pengujian kepercayaan nilai koefisien yang dihasilkan 0,226 nilai ini menujukkan bahwa setiap penambahan satu satuan dari bagi hasil, maka akan meningkatkan minat menjadi nasabah bank syariah sebesar 0,226. Nilai t hitung sebesar 2,380 dengan tingkat probabilitas signifikansi $0,019<0,05$. Artinya hipotesis ketiga diterima dengan kata lain kepercayaan memiliki pengaruh terhadap minat menjadi nasabah bank syariah. 
Hasil penelitian ini mendukung hasil penelitian yang dilakukan oleh Iranari (2017) yang menyatakan bahwa kepercayaan memiliki pengaruh yang positif dan signifikan terhadap perilaku menabung di bank syariah,artinya bahwa kepercayaan semakin meningkat, maka minat menabung juga semakin kuat. Hal ini sesuai dengan teori yang dikemukakan oleh Kotler (2002) yang menjelaskan bahwa komitmen pelanggan untuk tetap berhubungan dengan perusahaan karena adanya keyakinan atau kepercayaan kepada perusahaan sehingga akan melakukan pembelian ulang pada produk yang dihasilkan perusahaan. Dengan demikian variabel kepercayaan dapat mempengaruhi minat masyarakat menggunakan jasa perbankan syariah.

\section{Pengaruh Budaya Terhadap Minat Menjadi Nasabah Bank Syariah}

Hasil pengujian budaya nilai koefisien yang dihasilkan sebesar 0,269 nilai ini menujukkan bahwa setiap penambahan satu satuan dari bagi hasil, maka akan meningkatkan minat menjadi nasabah bank syariah sebesar 0,269 .. Nilai t hitung sebesar 4,649 dengan tingkat probabilitas signifikansi $0,00<0,05$. Artinya hipotesis keempat diterima dengan kata lain budaya memiliki pengaruh terhadap minat menjadi nasabah bank syariah.

Hasil penelitian ini senada dengan Pasrizal (2012) menyatakan bahwa kriteria terpenting dalam memilih bank adalah kesetiaan pada prinsip Islam artinya variabel ini memberikan kontribusi nyata dalam pengambilan keputusan seseorang menjadi nasabah. Budaya masyarakat yang baik akan menjadikan kehidupan masyarakat terpola dengan baik dan begitu sebaliknya. Perbankan dalam melakukan pemasaran harus memikirkan dan menganalisis terhadap nasabah sehingga bagaimana keputusannya dapat dipengaruhi oleh budaya. Dapat disimpulkan bahwa menguatnya budaya dapat memperkuat keputusan menjadi nasabah bank syariah khususnya dikota Padang yang sangat kental dengan nilai-nilai agamanya.

\section{KESIMPULAN, KETERBATASAN, SARAN \\ Kesimpulan}

Berdasarkan hasil pengolahan dan analisis data yang telah peneliti lakukan sebelumnya, maka dapat ditarik kesimpulan :

a. Bagi hasil tidak berpengaruh positif terhadap minat menjadi nasabah bank syariah.

b. Kelompok acuan tidak berpengaruh positif terhadap minat menjadi nasabah bank syariah.

c. Kepercayaan berpengaruh positif terhadap minat menjadi nasabah bank syariah.

d. Budaya berpengaruh positif terhadap minat menjadi nasabah bank syariah.

\section{Keterbatasan}

Meskipun peneliti telah berusaha merancang dan mengembangkan penelitian sedemikian rupa. Namun, masih terdapat beberapa keterbatasan dalam penelitian ini yang masih perlu diperbaiki bagi peneliti selanjutnya antara lain :

a. Penelitian ini hanya dilakukan di kota Padang sehingga tidak bisa dijadikan patokan untuk keseluruhan pada wilayah Sumatera Barat.

b. Masih terbatasnya jumlah responden yakni berjumlah 95 responden yang belum mencerminkan jumlahkeseluruhan nasabah bank syariah yang ada di kota Padang.

c. Penelitian ini hanya menggunakan 4 variabel bebas yang belum menjelaskan pengarug terhadap variabel terikat secara keseluruhan. 


\section{Saran}

Berdasarkan hasil dan keterbatasan dalam penelitian ini, penulis dapat memberikan beberapa saran yang dapat dipertimbangkan untuk mendapatkan hasil yang lebih baik lagi, antara lain sebagai berikut :

a. Diharapkan agar dapat memperluas wilayah penelitian mencakup nasabah bank syariah untuk seluruh wilayah yang ada di Sumatera Barat agar penelitian dapat di generalisasi.

b. Menambah jumlah sampel yang sebelumnya hanya dapat peneliti kumpulkan sejumlah 95 sampel, agar sampel yang digunakan menjadi lebih beragam dan hasil penelitian yang didapat lebih menggambarkan keadaan sebenarnya.

c. Menambah jumlah variabel penelitian diluar variabel yang telah peneliti gunakan agar lebih mampu menjelaskan pengaruh terhadap minat menjadi nasabah bank syariah

\section{DAFTAR PUSTAKA}

Ajzen, I .1987. Attitudes, Personality, \& Behavior. Chicago : Dorsey Press.

Ajzen, I. 2002. Perceeived Behavioral Control, Self Effecacy, Locus of Control and Theory of Planned Behavior, Journal of Applied Social Psycology. Vol. 32 No 4

Al-Qur'an Terjemahan

Andespa, Roni. 2017. Faktor-faktor Yang Mempengaruhi Minat Masyarakat Menabung di Bank Syariah. Maqdis : Jurnal Kajian Ekonomi Islam. Vol 2 No 1.

Andespa, Roni. 2017. Pengaruh Budaya dan Keluarga terhadap minat menabung nasabah di Bank Syariah. Maqdis : Jurnal Kajian Ekonomi Islam. Vol 2 No 1.

Antonio, MS. 2006. Bank Syariah Dari Teori Ke Praktik. Edisi Revisi 2003. Jakarta: Gema Insani

Anwar, Prabu. 2001. Manajemen Sumber Daya Manusia Pemasaran. Bandung: PT Remaja Rosda Karya.

Ascarya, Yumanita D. 2005. Bank Syariah : Gambaran Umum. Pusat Pendidikan dan Studi Kebanksentralan (PPSK) No 14. Jakarta : Bank Indonesia

Chayani AF, Saryadi dan Sendhang. 2013. Pengaruh Persepsi Bunga Bank dan Kualitas Pelayanan Terhadap Minat Menabung Pada Bank BNI Syariah di Kota Semarang. Jurnal Ilmu Administrasi. Vol. 2 No. 3.

Christianti. HE, Wulandari. D, Shandy. B \& Utomo HS. 2017. Factors that influence customers in using Islamic banking services. International Conference on Economics,Bisnis dan Studi Akuntansi (ICEBAST).

Crow and Crow. 2001. Psikologi Pendidikan. Surabaya: PT. Bina Ilmu.

Ghozali, Imam. 2005. Aplikasi Analisis Multivariate dengan Program SPSS. Edisi Ketiga, Badan Penerbit Universitas Diponegoro, Semarang.

Harahap, Sofyan, Syafri, Wiroso \& Yusuf, Muhammad. 2010. Akuntansi Perbankan Syariah. Edisi 4 Jakarta : Penerbit LPFEE Usakti.

Haris. 2012. Pengaruh Pengetahuan, Kualitas Pelayanan, Produk, dan Religiusitas terhadap Minat menggunakan Produk Simpanan pada Lemabaga Keuangan Syariah. Jurnal Ekonomi Islam, ISSN 2477-6157 I E- ISSN 2579-6534

Hurluck, E. B. 1990. Psikologi perkembangan Suatu Pendekatan Sepanjang Rentang Kehidupan. Edisi 5. Jakarta : Erlangga. 
Ismanto, K. 2018. Understanding on and Need for Syaria Insurance: A Case Study in Pekalongan, Central Java, Indonesia. Journal Accounting and Investment. Vol. 19 No. 2.

Jogiyanto. 2007. Sistem Informasi Keperilakuan. Edisi Revisi. Yogyakarta: Andi Offiset.

Karim, Adiwarman A. 2007. Bank Islam, Analisis Fiqih dan Keuangan. Jakarta : Raja Grafindo Persadan.

Kotler. P. 2002. Manajemen Pemasaran, Edisi Milenium. Jakarta, PT. Prehalindo

Kuncoro, Mudrajat. 2003 . Metode Riset Untuk Bisnis dan Ekonomi. Jakarta : Erlangga.

Kusmayadi. 2007. Pengaruh Relationship Quality Terhadap Loyalitas Nasabah Tabungan. STIE STAN Indonesia Mandiri

Lovelock Christopher. et. al. 2010. Pemasaran Jasa, Edisi 7, Jilid 2. Erlangga: Jakarta

Morgan, R.M. 1994. Relationship Between prifiders and Use Marketing Research: The Dynamic of Trust Within and Betv organitation. Journal of Marketing. Vol. 58.

Nisak, Arifatun. 2014. Pengaruh Kelompok Acuan dan Pengetahuan tentang Perbankan Syariah Terhadap Minat Menabung di Perbankan Syariah Semarang. Jurnal Ilmu Administrasi Bisnis. Vol. 2 NO. 1.

Nurhayati, S. 2015. Akuntansi Syariah di Indonesia. Edisi keempat. Jakarta : Salemba Empat

Oliver, Richard L. 2006. Statisfaction: A. Behavioral Persperctive on The Consumer. McGrawHill. New york.

Peter dan Olson (2002). Perilaku Konsumen dan Strategi Pemasaran. Terjemahan. Jakarta :Erlangga

Peter, JP dan Olson, Jc. 1999. Perilaku Konsumen dan Strategi Pemasaran. Erlangga. Jakarta

Prasetyo, Edwin. 2017. Pengaruh Tingkat Nisbah Bagi Hasil, Penerapan Akad, Citra Merek, Promosi dan Kualitas Pelayanan Terhadap Minat Menabung Pada Lembaga Keuangan Perbankan Syariah. Skripsi: Universitas UIN Syarif Hidayatullah.

Prassetio, Edwin. (2017). Pengaruh Tingkat Nisbah Bagi Hasil, Penerapan Akad, Citra Merek, Promosi, dan Kualitas Pelayanan terhadap Minat Menabung pada Lembaga Keuangan Perbankan Syariah (Studi Kasus Masyarakat Tangerang Selatan). Skripsi, Program Studi Ekonomi Syariah Fakultas Ekonomi Dan Bisnis Univwesitas Uin Syarif Hidayatullah Jakarta.

Putra AH. 2010. Pengaruh Persepsi atas Bagi Hasil dan Bunga Terhadap Minat Mahasiswa Widyatama Menjadi Nasabah Bank Syariah. Skripsi universitas Widyatama.

Saidurrahman, Soemitra. 2014. Buku Pegangan profesi Pengawas Syariah di Bank Syariah dan Asuransi Syariah. Medan: CV. Manhaji

Simorangkir. 2004. Pengantar Lembaga Keuangan Bank dan Non Bank Cetakan Kedua. Ghalia Indonesia

Sjahdeini, Remi S. 2014. Perbankan Syariah Produk-produk dan Aspek-aspek Hukumnya. Edisi Pertama. Jakarta : Kencana Prenadamia Group.

Sudarsono, Heri. 2012. Bank dan Lembaga Keuangan Syariah. Edisi Keempat. Yogyakarta: Ekonisia.

Sudjana. 2002. Metode Statistika. Bandung: Tarsito

Sugiyono. 2010. Metode penelitian Pendidikan Pendekatan Kuantitatif, Kualitatif dan R\&D. Bandung : Alfabeta

Sugiyono. 2012. Metode penelitian Pendidikan Pendekatan Kuantitatif, Kualitatif dan R\&D. Bandung : Alfabeta

Sukarno, Wibowo.2013. Ekonomi Mikro Islam. Pustaka Setia, Bandung. 
Sumantri, Bagja. 2014. Pengaruh Kualitas Pelayanan dan Produk Pembiayaan Terhadap Minat dan Keputusan Menjadi Nasabah di Bank Syariah. Jurnal Economia, Vol. 10 No 02, October 2014.

Susilowati. 2010. Pengaruh Persepsi dan Minat Mahasiswa Akuntansi Mengenai Profesi Akuntan. Skripsi: Universitas Negeri Semarang.

Tara N, Irshad M, Khan RM, Yamin Mahwish, Rizwan M. 2014. Factors Influencing the Adoption of Islamic Banking in Pakistan. Journal Adminsitrasi Public. Vol. 4 No 3.

Tarikotillah, Astik. (2017). Pengaruh Pengetahuan, Kelompok Acuan, Motivasi, Dan Lokasi Bank Terhadap Keputusan Masyarakat Muslim Melakukan Pembiayaan Di Bank Syariah ( Studi Kasus Pada Masyarakat Muslim Di Kota Surakarta). Skripsi, Jurusan Perbankan Syariah Fakultas Ekonomi dan Bisnis Islam Institut Agama Islam Negeri Surakarta

Wahab A dan Saleh RA. 2004. PsikologiSuatu Pengantar Dalam Perspektif Islam. Jakarta : Prenada Media.

Wahab, Sulaiman.2013. Marketing Mix dan Religi Terhadap Minat Masyarakat. Jurnal Manajemen dan Akuntansi. Vol 2 No 2 Agustus 2013.

Wahab, Wirdayani. 2016. Pengaruh Bagi Hasil Terhadap Minat Menabung di Bank Syariah. Jurnal Eknomi dan Bisnis islam, Vol. 01 No. 02 Juli-Desember 2016.

Wahyuni, Sri. 2017. Pengaruh Persepsi Kualitas Pelayanan dan Bagi Hasil Terhadap Minat Menjadi Nasabah Bank Syariah. Al-Tawassuh, Vol. 11 N0. 2.

www.haluanharian.com diakses tanggal 2 april 2018

www.ojk.go.id diakses tanggal 19 januari 2019

www.ojk.go.id diakses tanggal 18 januari 2019

Yuliana. 2004. Pengaruh Sikap Terhadap Pindah Kerja, Norma Subjekif, Perceived Behavioral Control terhadap Intensi Pindah Kerja Pada Pekerja Teknologi Informasi. Phronesis: Jurnal Ilmiah Psikologi Terapan.Vol 6 No 11. 